Traverso, Antonio and Mhando, Martin (Spring/Summer 2005) Salaam Cinema: unlikely journeys in documentary, Asian Cinema Journal 16(1) Special Issue: Asian Documentary Film: A Symposium, pp.108116.

\title{
Salaam Cinema: Unlikely Journeys in Documentary
}

After such roller-coaster fiction films as The Peddler (1987), The Cyclist (1989) and Marriage of the Blessed (1989), the Iranian film director Mohsen Makhmalbaf went on to celebrate the first centenary of cinema with the production of an explosive hybrid, Salaam Cinema (1995), with which he managed to rock the increasingly complacent boat of Western cinema at Cannes that year. The film opens with veritè sequences that show a crowd of thousands of aspirants, who responded to an advertisement by the renowned director, to audition for a part in his next film. Thereafter, Salaam Cinema depicts Makhmalbaf and his assistants in a film studio interviewing and recording the performances of those selected. In doing so, the film paints a fascinating portrait of the role that cinema's mythologies, especially those of Western cinema, play in Iranian culture. Drawing a powerful parallel between the cinematic and the social realms, this is a furiously self-reflexive and meta-textual film (where the film within the film is only an imagined and desired one), which effectively complicates any easy distinctions between fiction and documentary. Indeed, in order to generate this culturally situated meditation on the universal phenomenon of cinema, Makhmalbaf moves away from the fictional approach of his previous films. Salaam Cinema's key motivation is a desire to engage with the real, as witnessed in early cinema.

One hundred years earlier, as a new technology of visual representation and expression, cinema had attempted its very first steps in the form of semi-narrativised snapshots of social reality in the single-take films of the Lumière brothers. ${ }^{i}$ More often than not these early cinematic images have been perceived as direct windows onto the plenitude of a bygone world. Although not unproblematic, this perception may prompt the claim that at the moment of its inception cinema would have actually been delivered as the visual documentation rather than fictionalisation of the 
Traverso, Antonio and Mhando, Martin (Spring/Summer 2005) Salaam Cinema: unlikely journeys in documentary, Asian Cinema Journal 16(1) Special Issue: Asian Documentary Film: A Symposium, pp.108116.

filmmaker's surrounding reality. Thus, a direct line can be drawn between the Lumière's first Paris public screenings in December of 1895 and Makhmalbaf's 1995 international hit, a line whose edges and interstices tell us about the minoritarian story of the documentary as the cinematic par excellence. This is so despite the overwhelming way in which fiction has become synonymous with cinema in the globalised mainstream culture. Thus, if cinema were to begin with the Lumière and end with Makhmalbaf, then we would have it that cinema both arises and closes as documentary. This inclination towards the document, however, is not the only element connecting Salaam Cinema to the Lumière films and the documentary tradition. ${ }^{\text {ii }}$ The complication of the relationship between representation and referent is also common. In fact, both examples mobilise the perception that at the moment of the documentation of the events occurring before the camera the filmmaker's intervention cannot avoid contributing to their shaping and, to varied degrees, even becoming their main motivation. Indeed, while Makhmalbaf is overtly self-reflexive and deconstructive in Salaam Cinema, little attention has been given to the fact that the Lumière's allegedly unmediated images of the real were in fact densely designed visual texts (in terms of framing, composition, structure, and timing), which responded to long-lasting traditions of visualisation in painting and, more recently, photography. ${ }^{\text {iii }}$ Thus, to reformulate the former assertion: at the moment of its inception cinema does not only arise as documentary but its very desire for actuality is from the onset complicated by the needs of narrative and fiction. This oscillation of the cinematic text expresses an inherent ambiguity between the inclination to record and the tendency to imagine reality. This is what defines the cinema in its most intimate aspects, before and beyond the potential complexities and excesses of narrativisation and visual spectacle. This double-bound photographic quality of the cinematic (and by "photographic" we don't mean mimetic but the convergence of the recorded and the imagined), truly inscribes the journey, or better "journeys", of the documentary film form through its multiple and heterogenous histories of critical practice and theorisation. 
Traverso, Antonio and Mhando, Martin (Spring/Summer 2005) Salaam Cinema: unlikely journeys in documentary, Asian Cinema Journal 16(1) Special Issue: Asian Documentary Film: A Symposium, pp.108116.

Such an open conception of cinema is what Makhmalbaf seems to investigate in Salaam Cinema, a film that due to all its meta-textual and self-reflexive play demands to be critically revisited a decade after it premiered for Western audiences. In particular, our specific reconsideration of this film, points towards the need for a wider critical revision of the myriad trajectories of the documentary genre and of the theoretical discussions these have motivated. This revision, we believe, should in the first place problematise the Euro-American bias and teleological character of these histories, narratives and theorisations. ${ }^{\text {iv }}$ Such an encompassing reflection is obviously too broad an aim for a short paper. Therefore, we will limit ourselves here merely to the discreet analysis of two of many meaningful aspects to be discerned in Salaam Cinema, namely, its thematisation of power and its strategies of self-reflexivity.

The first aspect we would like to address is that of the film's overt meditation on power. Salaam Cinema interrogates the pre-conceptions that sustain the distinction between documentary and fiction by invoking the notion that in the first place cinema is about power and that this is true at all levels: from production and distribution to consumption and analysis. The film leads the viewer away from the comfort zone of passive entertainment and into a space of critical enjoyment. In fact, the film's structure itself is designed to make the viewer question both its premise and its messages. For example, the opening sequence depicting the crowd gathered outside the film studio seems to portray an Iran of sheep-like followers in their search of something new. However, as one follows the scenes of of multitudes fighting over handfuls of application forms and then chaotically and hazardously pushing their way through the recently opened gates, it is easy to be reminded of television news scenes in which refugees fight over food packs or desperately try to leave their homelands torn by disaster. Since the spontaneous and at times violent events depicted on screen are the direct result of Makhmalbaf's public call, the film directs the viewer's attention back to the director's own ethics. Furthermore, Salaam Cinema is a good example of how cinema's signifiers (for example, the director, the production process, the institution and language of cinema, and the star system) 
Traverso, Antonio and Mhando, Martin (Spring/Summer 2005) Salaam Cinema: unlikely journeys in documentary, Asian Cinema Journal 16(1) Special Issue: Asian Documentary Film: A Symposium, pp.108116.

reflect on society's power relations. Similarly, in the Iranian social structure religion, masculinity, patriarchy and the state offer comparable power positions to those of the cinema. In particular, the narrative function of religion in Salaam Cinema is intricately enmeshed with that of the Iranian social order: religion motivates characters, expresses identity and defines lifestyles. Likewise, the manifestation of spirituality in most Iranian films, and Middle Eastern cinema more generally, contributes to the understanding of characters and themes, with social relations nearly always being directly linked to religion. While Makhmalbaf seems conscious of the danger implicit in this, as he tries to distance religion from the state without much success, at times even just the language used by the people reveals the muddle that Islam and state power have become. On the other hand, all too often applications of Western paradigms to the analysis of Middle Eastern films deny or misrepresent the role of spirituality in these cultures, undermining the function of symbolic representations in film that pigeonhole Islam within confined and contrived spaces. The expression of spirituality in Middle Eastern cinema, as a means of asserting cultural specificity, narrowly becomes either an exotic object of desire or a dark source of "fundamentalist" threat for Western audiences.

Another very important element of power relations fore grounded in Salaam Cinema is the position of women both in society and cinema. While the most familiar image of Muslim women on Western screens is that of their faces covered by the veil, by which they are imagined as quiet, subservient, and oppressed, Salaam Cinema explicitly shows the agency of Iranian women and demonstrates that whenever required they will speak loudly. In the film we also witness how intricately interwoven the status of women is in Iranian culture: the veil here has its own avenues of vision. Incidentally, the position of women in Iran is not unlike that of cinema: like women's emancipation, Iranian cinema is a revolution of sorts.

The second aspect we want to discuss in this analysis of Salaam Cinema, which actively contributes to problematise the distinction between fiction and documentary, is the film's highly self-reflexive and deconstructive style. While Salaam Cinema can be viewed as a 
Traverso, Antonio and Mhando, Martin (Spring/Summer 2005) Salaam Cinema: unlikely journeys in documentary, Asian Cinema Journal 16(1) Special Issue: Asian Documentary Film: A Symposium, pp.108116.

rhetorical narrative Makhmalbaf also achieves deeper constructions of meaning through purely cinematic forms. The following are examples of his cinematic strategies into meaning production. Firstly, the "auditions" segment of the film begins with the presentation of a young man who pretends to be blind. After asking him some questions and instructing him to act, Makhmalbaf exposes the man's simulation. The young man cries and explains that since his task was to act he had decided to do it all the way through. Makhmalbaf opens this part of the film conceding a metaphorical value to the figure of the blind actor. Like this man, Makhmalbaf seems to suggest, Iranian people choose a pretended blindness and as a result can only see through cinema, as they are prompted by the director's instructions (as the blind man says, if the film's director wants him to see then he would play a seeing character). Interestingly, even after his charade has been exposed, having being told that he has succeeded to gain a part in the film (that is, in Salaam Cinema), the actor does not seem satisfied, as his own perceptions and the reality of cinema have not yet merged. The interplay between the actor's love for cinema and the "game" that the director now puts into motion suggests a growing fissure between the self-confidence and skills that an actor brings to the text and the power that the director wields. There is here an inter-textual defining of justice where power is constantly relocated on the director's side. While in many ways the history and praxis of global cinema conveys this reflexivity, this is particularly the case in Iranian cinema. ${ }^{\mathrm{v}}$ Chaudhuri and Finn have called this reflexive merging of the cinematic and the social a "fusion of reality and its poetic remake [which] do not just slot neatly inside each other they open onto each other overlapping" (Chaudhuri and Finn, 2003: 38-57). This intersection clearly occurs in Salaam Cinema in a scene in which two young female actors-to-be criticise Makhmalbaf for subjecting them to the abuse of his power. As a response they are asked to take up his role as director and significantly they reproduce the same abusive behaviour they had to endure themselves. The "image-time" of this film reflects the experience of post-colonial relations in Iran, where consecutive regimes have continue to yield oppressive power in the manner of their predecessors. ${ }^{\mathrm{vi}}$

Another cinematic strategy of meaning production sees Makhmalbaf sub-textually 
Traverso, Antonio and Mhando, Martin (Spring/Summer 2005) Salaam Cinema: unlikely journeys in documentary, Asian Cinema Journal 16(1) Special Issue: Asian Documentary Film: A Symposium, pp.108116.

arguing for the imminent falsity of documentary production while at an overt textual level maintaining that what the camera has recorded is the truth. This paradox is what drives the film forward. The premise of the whole film is that of the contradiction between its perceived truth and reality and the necessary fictionalising and performative ingredients required in the making of documentaries. As Makhmalbaf intervenes with the complicity of his crew the traditional uses of cinematic conventions, not only does the film become a self-reflexive narrative but also implicitly deconstructs the history of documentary theory. ${ }^{\text {vii }}$ For example, the multiple mirror reflections in Salaam Cinema are "image-movements," used to suggest its overt reflexivity. ${ }^{\text {viii }}$ Indeed, huge mirrors are used in the studio shoots, through which sometimes it is possible simultaneously to see the director's, crew's and actors in action. Thus, Salaam Cinema itself becomes a reflection of cinema.

Finally, the director further demonstrates how documentary is sustained by the complicity between filmmaker and viewer to imagine and believe the real through stylistic strategies. Auteurs are stylists who leave strong imprints on their works and they do this through voice-overs, on-camera presence, sign-posting of meanings, and structure. In the case of Salaam Cinema what began as an attempt to create a fiction film finally resulted in a problematic and problematising documentary, which not even its director recognises as such. This is the strength that Makhmalbaf brings to Salaam Cinema and that more generally characterises the New Iranian Cinema. In fact, one of the film's most crucial moments of negotiation between the real and the imagined/performative is the closing sequence, in which Makhmalbaf asks the two young women, who are shown holding the slate, whether they should write "To Be Continued" or "The End". The fact that this method of continuing endings is often used in Iranian films suggests that their endings are inscribed as partial and arbitrary because, in actual fact, there is no ending to the reality of the stories in Iran. Through such scenes Makhmalbaf signals the constructedness of documentary, suggests a dialogue between filmmaker, subject, crew and audience, and frees the expressive elements from a rigid subordination to convention. Salaam Cinema recognises and reveals its subjectivity, bias, intrusion, and artificiality, and, most 
Traverso, Antonio and Mhando, Martin (Spring/Summer 2005) Salaam Cinema: unlikely journeys in documentary, Asian Cinema Journal 16(1) Special Issue: Asian Documentary Film: A Symposium, pp.108116.

importantly, does not attempt to reduce or simplify the intrinsic complexity of "captured life". We would like to argue, then, that narrative in Salaam Cinema, not unlike fiction film, is driven not by what the documentary "actors" do in real life but by what they are asked to do in the reality of the making of the documentary. Documentary, in this sense, becomes a metaphor for both the social and subjective orders as it simultaneously reflects and constitutes life.

In this short discussion paper we have considered the open conception of cinema that Iranian director Mohsen Makhmalbaf articulates in the film Salaam Cinema (1995). We have stated that Makhmalbaf's tribute to the centenary of cinema in this film manifests the early desire of cinema to engage with the real. Thus, a genealogical link to the Lumière's 1895 films has been suggested, a link that reveals the minoritarian story of the documentary as the cinematic par excellence. This inclination towards the document that connects Salaam Cinema to the earliest films and the documentary tradition is also characterised by the complication of the relationship between representation and referent. Cinema's very desire for actuality is from the onset complicated by the needs of narrative and fiction. This convergence of the recorded and the imagined truly inscribes the journeys of the documentary film form through multiple and heterogenous histories of critical praxis and reflection. In our analysis we have argued that because of its complex meta-textual, self-reflexive, and deconstructive strategies, Salaam Cinema deserves serious critical reconsideration in the context of on-going theoretical discussions concerning documentary film. The brief analysis of specific aspects of Salaam Cinema undertaken in this paper, namely, its thematisation of power and its self-reflexive strategies, illustrates the need for a wider critical revision of the myriad trajectories of the documentary genre and of the theoretical discussions these have motivated. As already stated, a critical revision of such magnitude should begin from the problematisation of the Euro-American bias and teleological character of the histories, narratives and concepts in documentary theory, opening up this reflection to the multiple expressions of the world's cinemas. Indeed, non-Western filmmakers such as Makhmalbaf use cinematic languages that invite 
Traverso, Antonio and Mhando, Martin (Spring/Summer 2005) Salaam Cinema: unlikely journeys in documentary, Asian Cinema Journal 16(1) Special Issue: Asian Documentary Film: A Symposium, pp.108116.

Western audiences and critics to acknowledge the fact that the canonisation of Western cinema was in the first place effected upon preconceptions, misconceptions, and unawareness concerning other cinemas.

${ }^{\mathrm{i}}$ Even though to current film and television audiences the distinction between fiction and documentary may appear natural, this is the effect of historical developments. In fact, it is often accepted that the conceptualisation of this difference did not occur until the 1930s with Grierson, although it must be acknowledged that Russian film criticism had established by the 1920s a clear cut distinction between a cinema of reality and one of illusion.

ii According to Deutelbaum, "there is little reason to continue to regard [the Lumière's films] as naïve photographic renderings of natural events which happened to occur before the camera" (1983: 310). Also, Tom Gunning has discussed the links between early films and the avant-garde in two consecutive articles; see: "An Unseen Energy Swallows Space: The Space in Early Film and Its Relation to American Avant-Garde Film" and "The Cinema of Attractions: Early Film, Its Spectator and The Avant-Garde."

iii It is rarely observed, with exceptions such as the relevant essays in Fell's and Elsaesser $\&$ Barker's collections, that in some cases the depicted events were clearly directed for the purpose of its visual recording, such as Le Déjeuner de bébé and the comical L'Arroseur arrosé.

${ }^{\text {iv }}$ In order to achieve such an overarching critical revision it would be necessary to return to the genealogy of documentary modes famously devised by Bill Nichols and more recently criticised by Stella Bruzzi. The rationale behind this exercise would imply testing the five models suggested in Nichols's taxonomy against the textures of nonWestern films such as Salaam Cinema and subsequently assess the extent to which some or all of these are at play in the films. The assessment of the relative usefulness of Nichols's system outside the field of Western documentary should inevitably lead to an appraisal of both its limitations and strengths, opening up the theorisation of documentary outside the teleological and Euro-American parameters allegedly operating in his model (hence, the importance of Salaam Cinema as a documentary that is both offcentre and "revolutionary"). In this context, Bruzzi's critique of Nichols and her own contribution to contemporary documentary theory should prove pivotal in the development of a new, open vision. Indeed, Bruzzi's critique of Nichols' taxonomy focuses on two main points: the hegemonic status this theory has reached within theorisations of documentary and the historical necessity of its chronology. Needless to say Bruzzi's affirmation of the performative in documentary further underlines the multiplicity of form that this mode of imagistic communication embeds; see: Nichols's "The voice of documentary" and "Performing documentary," and Bruzzi's New Documentary: A Critical Introduction.

${ }^{\vee}$ To name a few examples: Makhmalbaf's The Apple and A Moment of Innocence, Kiarostami's Taste of Cherry and The Wind Will Carry Us, and Samira Makhmalbaf's The Circle. 
Traverso, Antonio and Mhando, Martin (Spring/Summer 2005) Salaam Cinema: unlikely journeys in documentary, Asian Cinema Journal 16(1) Special Issue: Asian Documentary Film: A Symposium, pp.108116.

vi Chaudhuri and Finn define "image-time" as the cinematic moment when a film uses associative rhetoric to make a political context possible (2003: 38-57).

${ }^{v i i}$ Makhmalbaf's strategies here clearly resemble those of Goddard in films such as Letter From Vietnam.

viii "Image-movement" is defined by Chaudhuri and Finn as mise-en-scène that concedes direct meaning to what is happening on screen (2003: 38-57).

\section{Works Cited}

Bruzzi, S., New Documentary: A Critical Introduction, London \& New York: Routledge, 2000 .

Chaudhuri, S., and H. Finn, Screen, vol. 44:1, Spring 2003, pp. 38-57.

Deutelbaum, M., "Structural Patterning in the Lumière Films, in J. Fell, ed., Film Before Griffith, Berkeley: University of California Press, 1983, pp. 299-310.

Nichols, B., "The Voice of Documentary" in A. Rosenthal, ed., New Challenges for Documentary, Berkeley: University of California Press, 1988, pp. 48-63

Nichols, B., "Performing Documentary," in Blurred Boundaries: Questions of Meaning in Contemporary Culture, Bloomington \& Indianapolis: Indiana University Press, 1994, pp. 92-106;

Gunning, T., “An Unseen Energy Swallows Space: The Space in Early Film and Its Relation to American Avant-Garde Film" in J. Fell, ed., Film Before Griffith, Berkeley: University of California Press, 1983, pp. 355-366,

Gunning, T., "The Cinema of Attractions: Early Film, Its Spectator and the AvantGarde," in T. Elsaesser \& A. Barker, eds., Early Cinema: Space, Frame, Narrative, London: BFI, 1990, pp. 56-62. 